\title{
Mean Performance of Nitrogen Use Efficiency and Grain Yield in Rice Genotypes
}

\author{
Rajesh Kunta ${ }^{*}$, Ramesh Thatikunta ${ }^{1}$ and D. Saida Naik ${ }^{2}$ \\ Department of Crop Physiology, Professor Jayashankar Telangana State Agricultural \\ University, Hyderabad- 500 030, Telangana, India \\ *Corresponding author
}

A B S T R A C T

\begin{tabular}{|l|}
\hline Ke y w o r d s \\
Nitrogen use \\
efficiency, Rice \\
genotypes, Grain \\
yield and mean \\
performance
\end{tabular}

\section{Introduction}

Rice (Oryza sativa L.) is one of the major food crops of the world. It is staple food for more than $60 \%$ of the global population and forms the cheapest source of food and energy (Zhao et al., 2011). Besides being the chief source of carbohydrate and protein in Asia, it also provides minerals and fibre. The present world population of 6.3 billion which may reach 8.5 billion by 2030 with an approximate rice consumers of five billion people thereby, increasing the demand of rice up to $38 \%$ by 2030. To meet this challenge there is a need to develop rice varieties with higher yield potential and greater yield stability (Lea and Miflin, 2003).

Nitrogen plays an important role in rice production, increased nitrogen application increases rice yield per unit area and nitrogen fertilizer has a key role in rice life cycle. Continuous increase in rice production has to be achieved with less nitrogen fertilizer by 
improving nitrogen use efficiency (NUE) through better nitrogen fertilizer management and development of new nitrogen use efficient rice varieties (Ahrens et al., 2010 and Kang et al., 2013).

The genotypic variation in NUE has been realized and however, plant traits that are associated with high grain yield and high NUE should be identified so that breeders are able to use these traits easily as selection criteria in the breeding programme to develop nitrogen use efficient varieties without the scare of playing with rice yield potential. Fundamental approach to develop cultivars with enhanced nitrogen use efficiency, in contrast to just improved yield requires evaluating the segregating population obtained by crossing low nitrogen efficient genotype to high nitrogen use efficient genotype and vice versa under native soil nitrogen condition so as to identify a nitrogen use efficient plants and compare its performance with that of other genotypes. In view of above facts an attempt was made to study genetic response for nitrogen use efficient and grain yield in rice genotypes.

\section{Materials and Methods}

Based on the yield performance and nitrogen use efficiency, six rice genotypes viz., MTU1001,WGL-2395, MTU-1010, Pothana, Bhadrakali and JGL-1798 were selected from Kharif-2011 and nine crosses viz., MTU1001 X Pothana, MTU- 1001 X Bhadrakali, MTU- 1001 X JGL-1798, WGL-2395 X Pothana, WGL-2395 X Bhdrakali, WGL2395 X JGL-1798, MTU-1010 X Pothana, MTU-1010 X Bhadrakali and MTU-1010 X JGL-1798 were made to produce $F_{1}$ generation in Rabi 2011-12. The $\mathrm{F}_{1}$ were selfed to produce $\mathrm{F}_{2}$ generations in Kharif 2012 and backcrossed with parents to produce 18 backcross generations. The experiment was carried out by six generations viz., $\mathrm{P}_{1}, \mathrm{P}_{2}$,
$\mathrm{F}_{1}, \mathrm{~F}_{2}, \mathrm{~B}_{1}$ and $\mathrm{B}_{2}$ were raised during Rabi2012-13 at college farm, College of Agriculture, Professor Jayashankar Telangana State Agricultural University, Rajendranagar, Hyderabad. Thirty day old seedlings were transplanted into $6 \mathrm{~m}^{2}(2 \mathrm{~m} \mathrm{X} \mathrm{3m})$ plots by adopting a spacing of $20 \mathrm{~cm}$ between rows and $15 \mathrm{~cm}$ between plants with in a row.. The recommended agronomic practices were followed to raise the crop. Observations were recorded for the following traits nitrogen use efficiency, No. of filled grains hill ${ }^{-1}, 1000$ seed weight and Grain yield $\left(\mathrm{kg} \mathrm{ha}^{-1}\right)$. Nitrogen use efficiency defined as the ratio of grain yield to applied fertilizer nitrogen is a key parameter for evaluating a crop cultivar. Grain from net plot area was thoroughly sun dried, threshed, cleaned and weight of grains was recorded and expressed in yield per hectare. The data were analyzed statistically following the method given by Singh and Chaudhary (2001).

\section{Results and Discussion}

The mean performances of six generations $\left(\mathrm{P}_{1}, \mathrm{P}_{2}, \mathrm{~F}_{1}, \mathrm{~F}_{2}, \mathrm{~B}_{1}\right.$ and $\left.\mathrm{B}_{2}\right)$ of nine crosses i.e., MTU- 1001 X Pothana, MTU- 1001 X Bhadrakali, MTU- 1001 X JGL-1798, WGL2395 X Pothana, WGL-2395 X Bhdrakali, WGL-2395 X JGL-1798, MTU-1010 X Pothana, MTU-1010 X Bhadrakali and MTU1010 X JGL-1798 generated and nitrogen use efficiency, grain yield and yield traits were analyzed and furnished below.

\section{Mean performance of generations for NUE and yield related traits in crosses of rice}

In the cross MTU-1001 X Pothana, significant difference was observed between generations (Table 1). Parent $\mathrm{P}_{1}$ (1458.67) significantly recorded higher number of filled grains hill ${ }^{-1}$ than the parent $P_{2}$ (1315.67). $F_{1}$ (1548.67) mean was higher than the both parents. $F_{2}$ (1467.85) generation also recorded higher 
than both the parents. Among the back crosses, $\mathrm{B}_{1}(1532.07)$ was higher than to $\mathrm{B}_{2}$ (1419.30) for number of filled grains hill ${ }^{-1}$. 1000 grain weight was significantly different in both the parents and parent $\mathrm{P}_{1}$ (16.58) recorded higher 1000 grain weight than $\mathrm{P}_{2}$ (15.39). The hybrid $F_{1}$ (15.72) recorded maximum 1000 grain weight than the $F_{2}$ (14.91). Among the back crosses, significant differences were observed between $\mathrm{B}_{1}$ (16.94) and $B_{2}$ (15.71) and $B_{1}$ was higher in 1000 grain weight than $B_{2}$ which recorded maximum 1000 grain weight compared to all generations. Nitrogen use efficiency (NUE) of parent $\mathrm{P}_{1}$ (42.96) recorded higher value than parent $\mathrm{P}_{2}$ (41.94). The hybrid $\mathrm{F}_{1}$ (45.73) recorded higher NUE compared to all generations. $F_{2}$ (42.54) recorded NUE similar to better parent. Among the back crosses, significant differences were observed between $B_{1}$ (45.17) and $B_{2}$ (43.60) and $B_{1}$ was higher in NUE than $B_{2}$ and parents. The parents deviated significantly for grain yield and parent $\mathrm{P}_{1}$ (5155.27) recorded higher yield than parent $\mathrm{P}_{2}$ (5033.30). Among the entire generations, the hybrid $\mathrm{F}_{1}(5487.67)$ recorded maximum grain yield, while $\mathrm{F}_{2}$ (5104.50) yielded higher grain yield than the parent $\mathrm{P}_{2}$. Among the back crosses, $\mathrm{B}_{1}$ (5420.79) recorded more yield than $\mathrm{B}_{2}$ (5231.81), which in turn yielded more than both parents. In cross MTU-1001 X Pothana the characters that could be improved by crossing included NUE and grain yield. The superiority of these characters was shown in $F_{1}$ or subsequent populations over parents.

In the cross MTU-1001 X Bhadrakali, parent $\mathrm{P}_{1}$ (1458.67) significantly recorded higher number of filled grains hill ${ }^{-1}$ than the parent $\mathrm{P}_{2}$ (1296.67). $F_{1}$ (1520.00) mean was higher than the both parents. $F_{2}(1451.85)$ was on par with better parent. Among the back crosses, $\mathrm{B}_{2}$ (1527.51) was higher than to $\mathrm{B}_{1}$ (1419.30) and superior among all generations. 1000 grain weight showed significant difference in both the parents and parent $\mathrm{P}_{1}$ (16.58) recorded higher value than $\mathrm{P}_{2}$ (15.05). The hybrid $F_{1}$ (15.50) recorded higher value than the $F_{2}$ (14.97). Among the back crosses, significant differences were observed between $B_{1}$ (15.71) and $B_{2}$ (17.25) and $B_{2}$ was higher in 1000 grain weight than $B_{1}$ which recorded maximum 1000 grain weight compared to all generations. Nitrogen use efficiency of parent $\mathrm{P}_{1}$ (42.96) recorded higher NUE than parent $\mathrm{P}_{2}$ (41.63). The hybrid $\mathrm{F}_{1}$ (45.17) recorded higher NUE compared to all generations. The $F_{2}$ (42.22) recorded lower NUE then better parent. Among the back crosses, significant differences were observed between $\mathrm{B}_{1}$ (43.60) and $B_{2}$ (44.79) and $B_{2}$ was higher in NUE than parents. The parents deviated significantly for grain yield and parent $\mathrm{P}_{1}$ (5155.27) recorded higher yield than parent $\mathrm{P}_{2}$ (4996.17). Among the entire generations, the hybrid $F_{1}(5420.35)$ recorded maximum grain yield, while $\mathrm{F}_{2}(5066.80)$ yielded higher grain yield than the $\mathrm{P}_{2}$. Among the back crosses, $\mathrm{B}_{2}$ (5374.48) recorded more yield than $\mathrm{B}_{1}$ (5231.81), which in turn yielded more than both parents. MTU-1001 X Bhadrakali in $\mathrm{F}_{1}$ generation showed significant improvement for all characters except 1000 grain weight. The seed at $F_{1}$ stage as such can be used as hybrid.

In the cross MTU-1001 X JGL-1798, parent $\mathrm{P}_{1}$ (1458.67) significantly recorded higher number of filled grains hill ${ }^{-1}$ than the parent $\mathrm{P}_{2}$ (1352.67). $F_{1}$ (1603.33) recorded higher value than all generations. $F_{2}(1525.60)$ generation values were also higher than both the parents. Among the back crosses, $\mathrm{B}_{1}$ (1527.51) showed higher value than to $B_{2}(1386.17)$ for number of filled grains hill ${ }^{-1} .1000$ grain weight was significantly different in both the parents and parent $\mathrm{P}_{1}(16.58)$ recorded values on par with 1000 grain weight than $\mathrm{P}_{2}$ (16.46). The hybrid $\mathrm{F}_{1}$ (18.56) recorded maximum 1000 grain weight than the $F_{2}$ (17.51). Among the back crosses, significant 
differences were observed between $\mathrm{B}_{1}$ (17.25) and $B_{2}$ (15.70) and $B_{1}$ was higher in 1000 grain weight than parents. Nitrogen use efficiency of parent $\mathrm{P}_{1}$ (42.96) recorded was higher than parent $\mathrm{P}_{2}$ (42.67). The hybrid $\mathrm{F}_{1}$ (46.51) recorded higher NUE compared to all generations. $F_{2}(43.02)$ recorded higher NUE than parent. Among the back crosses, significant differences were observed between $\mathrm{B}_{1}$ (44.79) and $\mathrm{B}_{2}$ (43.19) and $\mathrm{B}_{1}$ was higher in NUE than and parents. The parents slightly significantly for grain yield and parent $\mathrm{P}_{1}$ (5155.27) recorded higher yield than parent $\mathrm{P}_{2}$ (5120.63). Among the entire generations, the hybrid $\mathrm{F}_{1}$ (5581.30) recorded maximum grain yield, while $\mathrm{F}_{2}(5162.52)$ yielded higher grain yield than the parents. Among the back crosses, $\mathrm{B}_{1}$ (5374.48) recorded more yield than $\mathrm{B}_{2}(5182.30)$, which in turn yielded more than both parents.

MTU-1001X JGL-1798 shows superiority in all characters and was on par with parents. $F_{1}$ better performance observed in yield was also reflected in 1000 grain weight and has a basis in NUE.

In the cross WGL-2395 X Pothana, significant difference was observed between generations (Table 2). Number of filled grains hill ${ }^{-1}$ for parent $\mathrm{P}_{1}$ (1565.33) was significantly higher than the parent $\mathrm{P}_{2}$ (1315.67). The hybrid $\mathrm{F}_{1}$ (1451.00) mean was lower than better parent. $F_{2}(1379.60)$ recorded lower number of filled grains hill $^{-1}$ compared to parent $\mathrm{P}_{1}$. Among the back crosses, $\mathrm{B}_{2}$ (1534.43) was higher than $B_{1}$ (1386.17). 1000 grain weight was significantly different in both the parents and parent $\mathrm{P}_{1}$ (20.09) recorded higher value than $P_{2}$ (15.39). The hybrid $F_{1}(15.32)$ recorded lower value than the parents. $F_{2}(14.56)$ recorded lower 1000 grain weight among all generations. Among the back crosses, significant differences were observed between $B_{1}$ (15.70) and $B_{2}$ (19.29) and $B_{2}$ was higher in 1000 grain weight than
$B_{1}$. Nitrogen use efficiency of parent $P_{1}$ (44.82) recorded was higher than parent $\mathrm{P}_{2}$ (41.94). The hybrid $F_{1}$ (44.49) recorded lower and slightly on par value with better parent. $\mathrm{F}_{2}$ (41.79) recorded lower NUE among all generations. Among the back crosses, significant differences were observed between $\mathrm{B}_{1}$ (43.19) and $\mathrm{B}_{2}$ (45.35) and $\mathrm{B}_{2}$ which was higher in NUE than all generations. The parent $\mathrm{P}_{1}$ (5377.93) recorded higher yield than parent $\mathrm{P}_{2}$ (5033.30). The hybrid $\mathrm{F}_{1}$ (5338.83.35) recorded lower value than the better parent, while $\mathrm{F}_{2}$ (5015.06) yielded lower grain yield than the parents. Among the back crosses, $\mathrm{B}_{2}(5442.10)$ recorded more yield than $\mathrm{B}_{1}(5182.30)$, which in turn yielded more than both parents.

Performance of WGL-2395 X Pothana cannot be rated for superior performance in early generations $\left(\mathrm{F}_{1}\right)$ for crop improvement through characters like 1000 grain weight, NUE and grain yield populations have to be carried upto $\mathrm{B}_{2}$.

In the cross WGL-2395 X Bhadrakali, (Table 2) number of filled grains hill ${ }^{-1}$ for parent $P_{1}$ (1565.33) was significantly higher than parent $\mathrm{P}_{2}$ (1296.67). The $\mathrm{F}_{1}$ (1444.33) mean was lower than better parent. $F_{2}$ (1389.93) recorded lower number of filled grains hill ${ }^{-}$ ${ }^{1}$ compared to parent $\mathrm{P}_{1}$. Among the back crosses, $\mathrm{B}_{1}(1534.43)$ was higher than to $\mathrm{B}_{2}$ (1455.71). 1000 grain weight was significantly different between parents and parent $\mathrm{P}_{1}$ (20.09) recorded higher value than $P_{2}$ (15.05). The hybrid $F_{1}$ (14.95) recorded lower value than the parents. $F_{2}$ (14.35) recorded lower 1000 grain weight among all generations. Among the backcrosses, significant differences were observed between $B_{1}$ (19.29) and $B_{2}$ (18.04) and $B_{1}$ was higher in 1000 grain weight than $B_{2}$. Nitrogen use efficiency of parent $\mathrm{P}_{1}$ (44.82) recorded was higher than parent $\mathrm{P}_{2}$ (41.63). The hybrid $\mathrm{F}_{1}$ (44.28) recorded lower and slightly on par 
value with better parent. $F_{2}$ (41.61) recorded lower NUE among all generations and was on par with parent $\mathrm{P}_{2}$. Among the back crosses, $\mathrm{B}_{1}$ (45.35) recorded higher NUE than all generations. Parent $\mathrm{P}_{1}$ (5377.93) recorded higher yield than parent $\mathrm{P}_{2}$ (4996.17). The hybrid $F_{1}(5313.77)$ recorded lower value than the better parent, while $F_{2}$ (4993.16) yielded lower grain yield than the parents. Among the back crosses, $\mathrm{B}_{2}(5442.10)$ recorded more yield than $\mathrm{B}_{1}$ (5309.18), which in turn yielded more than both parents. Data revealed that parent $\mathrm{P}_{1}$ (WGL-2395) was significantly superior for NUE, yield and yield contributing characters. Thus $\mathrm{P}_{1}$ can be used as for transfer of characters in other crosses for bringing about heterosis.

Table.1 Mean performance of generations for NUE, yield and yield related traits in crosses of rice genotypes

\begin{tabular}{|c|c|c|c|c|c|c|c|c|}
\hline Trait/cross & $\mathbf{P}_{1}$ & $\mathbf{P}_{2}$ & $\mathbf{F}_{1}$ & $\mathbf{F}_{2}$ & $\mathbf{B}_{1}$ & $\mathbf{B}_{2}$ & S.Em \pm & C.D (5\%) \\
\hline \multicolumn{9}{|c|}{ MTU-1001 X Pothana } \\
\hline $\begin{array}{l}\text { No. of filled } \\
\text { grains hill-1 }^{-1}\end{array}$ & 1458.67 & 1315.67 & 1548.67 & 1467.85 & 1532.07 & 1419.30 & 34.30 & 99.06 \\
\hline $\begin{array}{l}1000 \text { grain wt } \\
\text { (g) }\end{array}$ & 16.58 & 15.39 & 15.72 & 14.91 & 16.94 & 15.71 & 0.41 & 1.20 \\
\hline NUE & 42.96 & 41.94 & 45.73 & 42.54 & 45.17 & 43.60 & 0.41 & 1.18 \\
\hline $\begin{array}{l}\text { Grain yield } \\
\left(\mathrm{kg} \mathrm{ha}^{-1}\right)\end{array}$ & 5155.27 & 5033.30 & 5487.67 & 5104.50 & 5420.79 & 5231.81 & 40.29 & 116.36 \\
\hline \multicolumn{9}{|c|}{ MTU-1001 X Bhadrakali } \\
\hline $\begin{array}{l}\text { No. of filled } \\
\text { grains hill }^{-1}\end{array}$ & 1458.67 & 1296.67 & 1520.00 & 1451.27 & 1419.30 & 1527.51 & 36.06 & 104.14 \\
\hline $\begin{array}{l}1000 \text { grain wt } \\
\text { (g) }\end{array}$ & 16.58 & 15.05 & 15.50 & 14.97 & 15.71 & 17.25 & 0.45 & 1.30 \\
\hline NUE & 42.96 & 41.63 & 45.17 & 42.22 & 43.60 & 44.79 & 0.39 & 1.13 \\
\hline $\begin{array}{l}\text { Grain yield } \\
\left(\mathrm{kg} \mathrm{ha}^{-1}\right)\end{array}$ & 5155.27 & 4996.17 & 5420.35 & 5066.80 & 5231.81 & 5374.48 & 37.46 & 108.19 \\
\hline \multicolumn{9}{|c|}{ MTU-1001 X JGL-1798 } \\
\hline $\begin{array}{l}\text { No. of filled } \\
\text { grains hill }^{-1}\end{array}$ & 1458.67 & 1352.67 & 1603.33 & 1525.60 & 1527.51 & 1386.17 & 30.93 & 89.31 \\
\hline $\begin{array}{l}1000 \text { grain wt } \\
\text { (g) }\end{array}$ & 16.58 & 16.46 & 18.56 & 17.51 & 17.25 & 15.70 & 0.27 & 0.79 \\
\hline NUE & 42.96 & 42.67 & 46.51 & 43.02 & 44.79 & 43.19 & 0.38 & 1.10 \\
\hline $\begin{array}{l}\text { Grain yield } \\
\left(\mathrm{kg} \mathrm{ha}^{-1}\right)\end{array}$ & 5155.27 & 5120.63 & 5581.30 & 5162.52 & 5374.48 & 5182.30 & 40.17 & 115.99 \\
\hline
\end{tabular}


Table.2 Mean performance of generations for NUE, yield and yield related traits in crosses of rice genotypes

\begin{tabular}{|c|c|c|c|c|c|c|c|c|}
\hline \multirow[t]{2}{*}{ Trait/cross } & $\mathbf{P}_{1}$ & $\mathbf{P}_{2}$ & $\mathbf{F}_{1}$ & $\mathbf{F}_{2}$ & $\mathbf{B}_{1}$ & $\mathbf{B}_{2}$ & S.Em \pm & C.D (5\%) \\
\hline & \multicolumn{8}{|c|}{ WGL-2395 X Pothana } \\
\hline $\begin{array}{l}\text { No. of filled grains } \\
\text { hill }^{-1}\end{array}$ & 1565.33 & 1315.67 & 1451.00 & 1379.60 & 1386.17 & 1534.43 & 26.28 & 75.90 \\
\hline 1000 grain wt (g) & 20.09 & 15.39 & 15.32 & 14.56 & 15.70 & 19.29 & 0.11 & 0.31 \\
\hline NUE & 44.82 & 41.94 & 44.49 & 41.79 & 43.19 & 45.35 & 0.30 & 0.86 \\
\hline Grain yield (kg ha ${ }^{-1}$ ) & 5377.93 & 5033.30 & 5338.83 & 5015.06 & 5182.30 & 5442.10 & 30.12 & 86.97 \\
\hline \multicolumn{9}{|c|}{ WGL-2395 X Bhadrakali } \\
\hline $\begin{array}{l}\text { No. of filled grains } \\
\text { hill }^{-1}\end{array}$ & 1565.33 & 1296.67 & 1444.33 & 1389.93 & 1534.43 & 1455.71 & 29.31 & 84.64 \\
\hline 1000 grain wt $(\mathrm{g})$ & 20.09 & 15.05 & 14.95 & 14.35 & 19.29 & 18.04 & 0.15 & 0.44 \\
\hline NUE & 44.82 & 41.63 & 44.28 & 41.61 & 45.35 & 44.24 & 0.30 & 0.87 \\
\hline Grain yield (kg ha ${ }^{-1}$ ) & 5377.93 & 4996.17 & 5313.77 & 4993.16 & 5442.10 & 5309.18 & 29.79 & 86.04 \\
\hline \multicolumn{9}{|c|}{ WGL-2395 X JGL-1798 } \\
\hline $\begin{array}{l}\text { No. of filled grains } \\
\text { hill }^{-1}\end{array}$ & 1565.33 & 1352.67 & 1460.00 & 1400.60 & 1455.71 & 1454.12 & 24.34 & 70.29 \\
\hline 1000 grain wt (g) & 20.09 & 16.46 & 15.45 & 14.80 & 18.04 & 15.93 & 0.12 & 0.36 \\
\hline NUE & 44.82 & 42.67 & 44.62 & 41.86 & 44.24 & 43.77 & 0.26 & 0.77 \\
\hline Grain yield (kg ha ${ }^{-1}$ ) & 5377.93 & 5120.63 & 5354.60 & 5023.64 & 5309.18 & 5252.79 & 27.26 & 78.72 \\
\hline
\end{tabular}

Figure.1 Mean performance of MTU-1010 X JGL-1798 with respect to nitrogen use efficiency (NUE) of rice genotypes

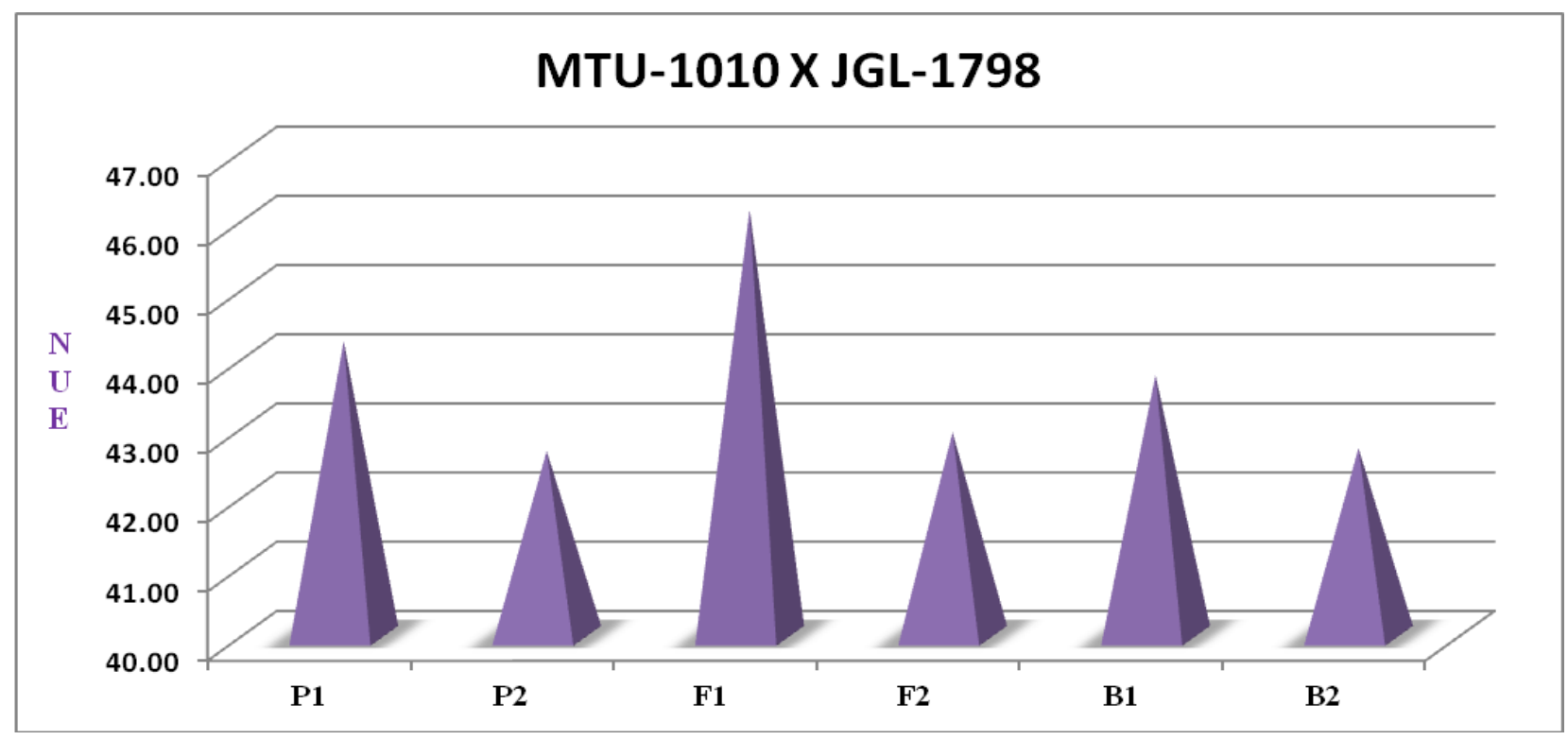


Table.3 Mean performance of generations for NUE, yield and yield related traits in crosses of rice genotypes

\begin{tabular}{|c|c|c|c|c|c|c|c|c|}
\hline Trait/cross & $\mathbf{P}_{1}$ & $\mathbf{P}_{2}$ & $\mathbf{F}_{1}$ & $\mathbf{F}_{2}$ & $\mathbf{B}_{1}$ & $\mathbf{B}_{2}$ & S.Em \pm & C.D (5\%) \\
\hline \multicolumn{9}{|c|}{ MTU-1010 X Pothana } \\
\hline $\begin{array}{l}\text { No. of filled grains } \\
\text { hill }^{-1}\end{array}$ & 1502.67 & 1315.67 & 1510.33 & 1425.93 & 1454.12 & 1378.75 & 28.38 & 81.96 \\
\hline 1000 grain wt (g) & 22.05 & 15.39 & 16.65 & 14.94 & 15.93 & 15.86 & 0.54 & 1.56 \\
\hline NUE & 44.26 & 41.94 & 45.56 & 42.64 & 43.77 & 43.35 & 0.40 & 1.14 \\
\hline Grain yield $\left(\mathrm{kg} \mathrm{ha}^{-1}\right)$ & 5311.50 & 5033.30 & 5467.40 & 5116.64 & 5252.79 & 5202.50 & 38.73 & 111.83 \\
\hline \multicolumn{9}{|c|}{ MTU-1010 X Bhadrakali } \\
\hline $\begin{array}{l}\text { No. of filled grains } \\
\text { hill }^{-1}\end{array}$ & 1502.67 & 1296.67 & 1473.00 & 1410.93 & 1378.75 & 1454.07 & 32.74 & 94.55 \\
\hline 1000 grain wt $(g)$ & 22.05 & 15.05 & 16.07 & 15.01 & 15.86 & 15.65 & 0.56 & 1.63 \\
\hline NUE & 44.26 & 41.63 & 45.07 & 42.21 & 43.35 & 43.77 & 0.39 & 1.13 \\
\hline Grain yield $\left(\mathrm{kg} \mathrm{ha}^{-1}\right)$ & 5311.50 & 4996.17 & 5408.70 & 5065.20 & 5202.50 & 5252.39 & 36.19 & 104.51 \\
\hline \multicolumn{9}{|c|}{ MTU-1010 X JGL-1798 } \\
\hline $\begin{array}{l}\text { No. of filled grains } \\
\text { hill }^{-1}\end{array}$ & 1502.67 & 1352.67 & 1578.67 & 1487.85 & 1454.07 & 1368.53 & 27.08 & 78.21 \\
\hline 1000 grain wt (g) & 22.05 & 16.46 & 19.93 & 18.38 & 15.65 & 15.37 & 0.43 & 1.25 \\
\hline NUE & 44.26 & 42.67 & 46.17 & 42.94 & 43.77 & 42.71 & 0.37 & 1.08 \\
\hline Grain yield $\left(\mathrm{kg} \mathrm{ha}^{-1}\right)$ & 5311.50 & 5120.63 & 5539.80 & 5153.04 & 5252.39 & 5125.73 & 38.83 & 112.14 \\
\hline
\end{tabular}

Figure.2 Mean performance of MTU-1010 X JGL-1798 with respect to grain yield of rice genotypes

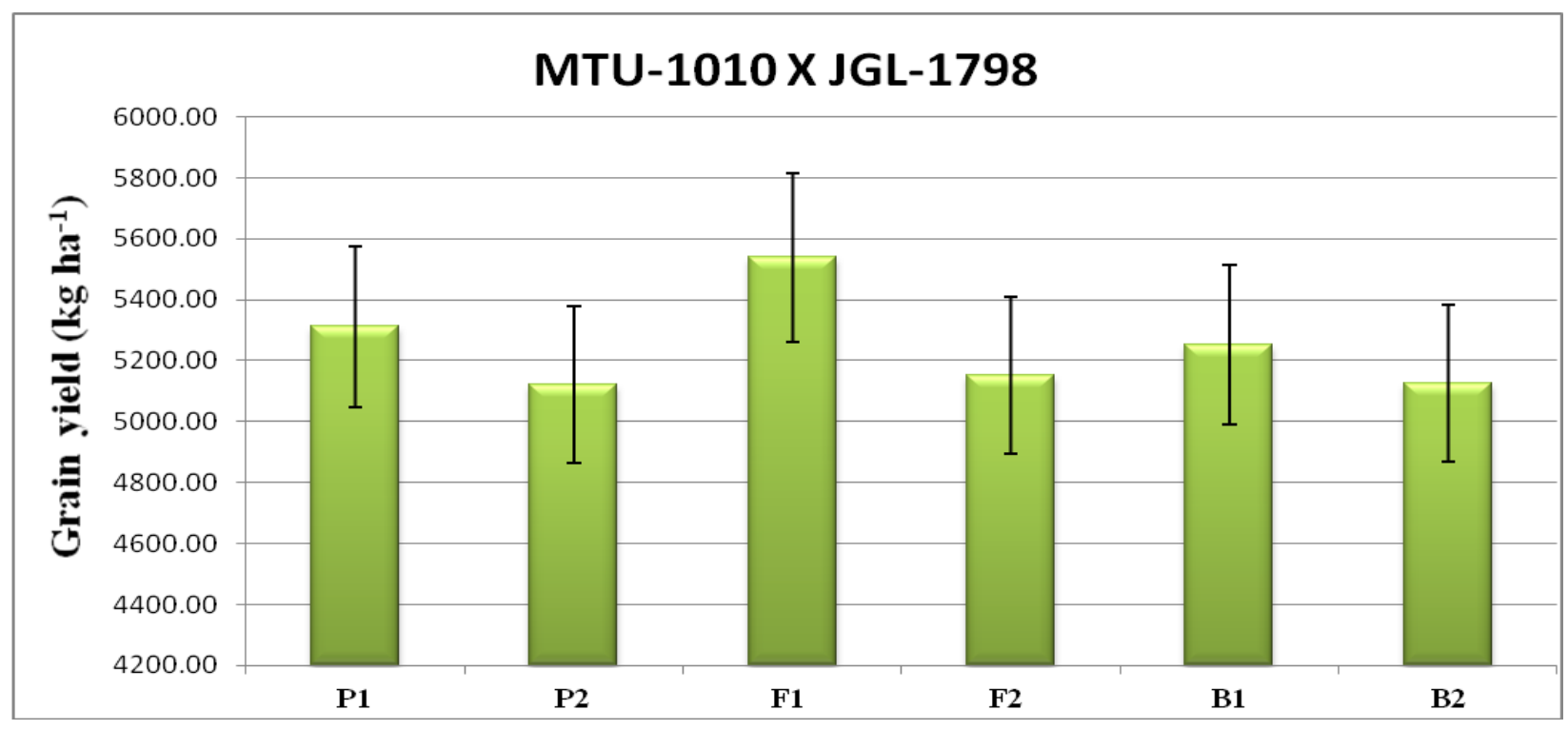


In the cross WGL-2395 X JGL-1798, (Table 2) number of filled grains hill ${ }^{-1}$ for parent $P_{1}$ (1565.33) significantly recorded higher value than the parent $\mathrm{P}_{2}$ (1352.67). The $\mathrm{F}_{1}$ (1460.00) mean was lower than better parent. $F_{2}$ (1400.60) recorded lower number of filled grains hill ${ }^{-1}$ compared to parent $\mathrm{P}_{1}$. Among the back crosses, $\mathrm{B}_{1}(1455.71)$ was similar to $\mathrm{B}_{2}$ (1454.12). 1000 grain weight was significantly different in both the parents and parent $\mathrm{P}_{1}$ (20.09) recorded higher value than $\mathrm{P}_{2}$ (16.46). The hybrid $F_{1}$ (15.45) recorded lower than the parents. F2 (14.80) recorded lower 1000 grain weight among all generations. Among the back crosses, significant differences were observed between $\mathrm{B}_{1}$ (18.04) and $\mathrm{B}_{2}$ (15.93) and $\mathrm{B}_{1}$ was higher in 1000 grain weight than $B_{2}$. Nitrogen use efficiency of parent $\mathrm{P}_{1}$ (44.82) recorded higher value than parent $\mathrm{P}_{2}$ (42.67). The hybrid $F_{1}$ (44.62) recorded lower and slightly on par value with better parent. $F_{2}$ (41.86) recorded lower NUE among all generations. Among the back crosses, $\mathrm{B}_{1}$ (44.24) recorded higher NUE than and $B_{2}$ (43.77). The parent $\mathrm{P}_{1}$ (5377.93) recorded higher yield than parent $\mathrm{P}_{2}$ (5120.63). The hybrid $\mathrm{F}_{1}$ (5354.60) recorded lower value than the better parent, while $F_{2}(5023.64)$ yielded lower grain yield than the parents. Among the back crosses, $\mathrm{B}_{1}$ (5309.18) recorded more yield than $\mathrm{B}_{2}$ (5252.79). Variable performance was shown by the cross WGL-2395 X JGL-1798. Parents involved were on par with $\mathrm{F}_{1}, \mathrm{~B}_{1}$ and $\mathrm{B}_{2}$.

In the cross MTU-1010 X Pothana, the data (Table 3) revealed that parent $P_{1}$ (1502.67) significantly recorded higher number of filled grains hill ${ }^{-1}$ than the parent $\mathrm{P}_{2}$ (1315.67). $\mathrm{F}_{1}$ (1510.33) mean was higher than the both parents. $F_{2}$ (1425.93) recorded higher value than the $\mathrm{P}_{2}$. Among the back crosses, $\mathrm{B}_{1}$ (1454.12) was higher than to $B_{2}$ (1378.75) for number of filled grains hill $^{-1}$. 1000 grain weight was significantly different in both the parents and parent $\mathrm{P}_{1}$ (22.05) recorded higher
1000 grain weight than $\mathrm{P}_{2}$ (15.39). The hybrid $F_{1}$ (16.65) recorded maximum 1000 grain weight than $F_{2}$ (14.94). Among the back crosses, $\mathrm{B}_{2}$ (15.86) was almost similar to $\mathrm{B}_{1}$ (15.93). Nitrogen use efficiency of parent $P_{1}$ (44.26) was higher than parent $\mathrm{P}_{2}$ (41.94). The hybrid $F_{1}$ (45.56) recorded higher NUE compared to all generations. $F_{2}$ (42.64) recorded lower NUE than better parent. Among the back crosses, $B_{1}$ (43.77) and $B_{2}$ (43.35) was almost similar in NUE. Parent $P_{1}$ (5311.50) recorded higher grain yield than parent $\mathrm{P}_{2}$ (5033.30). Among the entire generations, hybrid $\mathrm{F}_{1}$ (5467.40) recorded maximum grain yield, while $F_{2}$ (5116.64) yielded higher grain yield than the parent $\mathrm{P}_{2}$. Among the back crosses, $\mathrm{B}_{1}$ (5252.79) recorded more yield than $\mathrm{B}_{2}$ (5202.50).

In the cross MTU-1010 X Bhadrakali, (Table 3) parent $P_{1}$ (1502.67) significantly recorded higher number of filled grains hill ${ }^{-1}$ than the parent $\mathrm{P}_{2}$ (1296.67). The $\mathrm{F}_{1}$ (1473.00) mean was higher than $\mathrm{P}_{2}$. The $\mathrm{F}_{2}$ (1410.93) recorded higher number of filled grains hill ${ }^{-1}$ than $\mathrm{P}_{2}$. Among the back crosses, $\mathrm{B}_{2}$ (1454.07) was higher than to $B_{1}(1378.75)$ for number of filled grains hill $^{-1}$. 1000 grain weight was significantly different in both the parents and parent $\mathrm{P}_{1}$ (22.05) recorded higher 1000 grain weight than $\mathrm{P}_{2}$ (15.05). The hybrid $\mathrm{F}_{1}$ (16.07) recorded maximum 1000 grain weight than the $F_{2}$ (15.01). Among the back crosses, $B_{1}$ (15.86) was almost similar in 1000 grain weight to $B_{2}$ (15.65). Nitrogen use efficiency of parent $\mathrm{P}_{1}$ (44.26) recorded was higher than parent $\mathrm{P}_{2}$ (41.63). The hybrid $\mathrm{F}_{1}$ (45.07) recorded higher NUE compared to all generations. $F_{2}$ (42.21) recorded lower NUE than better parent. Among the back crosses, $\mathrm{B}_{2}$ (43.77) and $\mathrm{B}_{1}$ (43.35) were almost similar. Grain yield, parent $\mathrm{P}_{1}$ (5311.50) recorded higher yield than parent $\mathrm{P}_{2}$ (4996.17). Among the entire generations, the hybrid $F_{1}(5408.70)$ recorded maximum grain yield, while $F_{2}(5065.20)$ yielded higher grain 
yield than the parent $\mathrm{P}_{2}$. Among the back crosses, $\mathrm{B}_{2}$ (5252.39) recorded more yield than $\mathrm{B}_{1}$ (5202.50). Parental performance was superior in the cross MTU-1010 X Bhadrakali.

In the cross MTU-1010 X JGL-1798, parent $\mathrm{P}_{1}$ (1502.67) significantly recorded higher number of filled grains hill ${ }^{-1}$ than the parent $\mathrm{P}_{2}$ (1352.67). $F_{1}$ (1578.67) value was higher among all the generations. $F_{2}$ (1487.85) generation also recorded higher value than the parent $\mathrm{P}_{2}$. Among the back crosses, $\mathrm{B}_{1}$ (1454.07) was higher than to $B_{2}$ (1368.53) for number of filled grains hill ${ }^{-1} .1000$ grain weight was significantly different in both the parents and parent $P_{1}$ (22.05) recorded higher 1000 grain weight than $\mathrm{P}_{2}$ (16.46). The hybrid $F_{1}$ (19.93) recorded maximum 1000 grain weight than the $F_{2}$ (18.38). Among the back crosses, no significant differences were observed between $\mathrm{B}_{1}$ (15.65) and $\mathrm{B}_{2}$ (15.37). Nitrogen use efficiency of parent $\mathrm{P}_{1}$ (44.26) was higher than parent $P_{2}$ (42.67). The hybrid $F_{1}$ (46.17) recorded higher NUE compared to all generations. $F_{2}$ (42.94) recorded lower NUE than better parent. Among the back crosses, significant differences were observed and $B_{1}$ (43.77) recorded higher NUE than $B_{2}$ (42.71) (Fig. 1). Parent $\mathrm{P}_{1}$ (5311.50) recorded higher grain yield than parent $\mathrm{P}_{2}$ (5120.63). Among the entire generations, the hybrid $\mathrm{F}_{1}$ (5539.80) recorded maximum grain yield, while $F_{2}(5153.04)$ yielded higher grain yield than parent $\mathrm{P}_{2}$. Among the back crosses, $\mathrm{B}_{1}$ (5252.39) recorded more yield than $\mathrm{B}_{2}$ (5125.73) (Fig. 2). Superiority of the cross MTU-1010 X JGL-1798 was expressed at by grain yield and NUE.

The mean data obtained from six generations of the nine cross combinations for NUE and yield traits were subjected to generation mean analysis using scaling testes to test the fitness of additive-dominance model and Haymans six parameter model to find the significant inter-allelic interactions.
Predominance of dominance component over additive component and the importance of epistatic interactions, hybrid breeding can be a better strategy for rice improvement provided hybrid seed production is relatively simple and economically viable. Recurrent selection, biparental mating and diallel selective mating system may also be profitable to exploit both additive and nonadditive components for bringing about improvement in grain yield and its attributes. Such a strategy will help in increasing the frequency of favorable alleles while maintaining the genetic variation in breeding population (Hallauer and Miranda, 1988 and Doerksen et al., 2003).

To sum up, with regard to rice breeding to earn high yield variety, it is very important to know about genetic structure of each trait including inheritability, gene mode of action and number of controller genes. This information makes breeders able to design appropriate strategies. Generation mean analysis can be commonly used for evaluating of effect of those genes which are involved in quantitative traits (Kearsy and Pooni, 1996).

Estimates of genetic effects using generation mean analysis, genes of like effects must be completely associated with the parents. Therefore, selection of parents contrasting for the trait being measured is crucial for this type of investigation. Any dispersal of like genes among the two parents may cause cancelling of some effects, resulting in the underestimation of additive $(d)$, additive $\times$ additive $(i)$ and additive $\times$ dominance $(j)$ effects (Wilson et al., 2000).

From the investigation it can be concluded that the cultivars with high uptake efficiency had higher nitrogen contents than cultivars with low uptake efficiency from nitrogen application. Therefore, the cultivars with high uptake efficiency could reduce the losses of $\mathrm{N}$ and facilitates increased $\mathrm{N}$ uptake and result 
in the development of superior nitrogen use efficient rice cultivars. Improvement of traits with simple selection techniques will not be able to fix superior lines in the early segregating generations. Knowledge about the way genes act and interact will determine the breeding system to optimize gene action more efficiently to elucidate the role of breeding systems in the evolution of crop plants.

\section{References}

Ahrens T D, Lobell D B, Ortiz-Monasterio J I, Li Y, Matson P A. 2010. Narrowing the agronomic yield gap with improved nitrogen use efficiency: a modeling approach. Ecological Applicants, 20: 91-100.

Doerksen, T.K., Kannenberg, L and Lee, E. 2003. Effects of recurrent selection on combining ability in maize breeding population. Crop science. 43: 16521668.

Hallauer, A.R and Miranda, J.B. 1988. Quantitative Genetics in Maize Breeding. The Iowa State University Press, Ames, USA.

Kang S G, Hassan M S, Sang W G, Min-Kyu Choi, Young-Doo Kim, Hong-Kyu
Park, Chowdhury A and Jeom-Ho Lee. 2013. Nitrogen use efficiency of high yielding japonica rice (Oryza sativa L.) influenced by variable nitrogen applications. Korean journal of Crop Science 58(3): 213-219.

Keasrey, M.J. and Pooni, H.S. 1996. The Genetical Analysis of Quantitative Traits. Chapman and Hall. First Edition. London.

Lea, P. J. and Miflin, B. J. Glutamate synthase and the synthesis of glutamate in plants. Plant Physiol. Biochem., 41: 555- 564 (2003).

Singh, R. K and Chaudhary, B. D. 2001. Biometrical Methods in Quantitative Genetic Analysis. Kalyani Publishers New Delhi India. 79-101.

Wilson, J.A., Glover, D.V and Nyquist, W.E. 2000. Genetic effects of the soft starch (h) and background loci on volume of starch granules in five inbreds of maize. Plant Breeding. 119: 173-176.

Zhao L, Wu L, Wu M and Li Y. 2011. Nutrient uptake and water use efficiency as affected by modified rice cultivation methods with irrigation. Paddy Water Environment, 9: 25-32.

\section{How to cite this article:}

Rajesh Kunta, Ramesh Thatikunta and Saida Naik, D. 2020. Mean Performance of Nitrogen Use Efficiency and Grain Yield in Rice Genotypes. Int.J.Curr.Microbiol.App.Sci. 9(05): 22052214. doi: https://doi.org/10.20546/ijcmas.2020.905.251 